\title{
Review
}

\section{Exercising New Neurons to Vanquish Alzheimer Disease}

\author{
María Llorens-Martín $\mathrm{n}^{\mathrm{a}, \mathrm{b}, \mathrm{c}, *}$ \\ a Department of Molecular Neuropathology, Centro de Biología Molecular “Severo Ochoa”, CBMSO, \\ CSIC-UAM, Madrid, Spain \\ ${ }^{\mathrm{b}}$ Center for Networked Biomedical Research on Neurodegenerative Diseases CIBERNED, Madrid, Spain \\ ${ }^{\mathrm{c}}$ Department of Molecular Biology, Faculty of Sciences, Universidad Autónoma de Madrid, Madrid, Spain
}

Accepted: 21 March 2018

Published: 21 May 2018

\begin{abstract}
Alzheimer disease (AD) is the most common type of dementia in individuals over 65 years of age. The neuropathological hallmarks of the condition are Tau neurofibrillary tangles and Amyloid- $\beta$ senile plaques. Moreover, certain susceptible regions of the brain experience a generalized lack of neural plasticity and marked synaptic alterations during the progression of this as yet incurable disease. One of these regions, the hippocampus, is characterized by the continuous addition of new neurons throughout life. This phenomenon, named adult hippocampal neurogenesis (AHN), provides a potentially endless source of new synaptic elements that increase the complexity and plasticity of the hippocampal circuitry. Numerous lines of evidence show that physical activity and environmental enrichment (EE) are among the most potent positive regulators of AHN. Given that neural plasticity is markedly decreased in many neurodegenerative diseases, the therapeutic potential of making certain lifestyle changes, such as increasing physical activity, is being recognised in several non-pharmacologic strategies seeking to slow down or prevent the progression of these diseases. This review article summarizes current evidence supporting the putative therapeutic potential of EE and physical exercise to increase AHN and hippocampal plasticity both under physiological and pathological circumstances, with a special emphasis on neurodegenerative diseases and AD.
\end{abstract}

Keywords: Adult hippocampal neurogenesis, neural plasticity, Alzheimer disease, neuroprotection, newborn granule neuron, memory

\section{ADULT HIPPOCAMPAL NEUROGENESIS (AHN) AND NEURODEGENERATIVE DISEASES: INTRODUCTORY NOTES}

During adulthood, the addition of new neurons under physiological conditions occurs naturally in two regions of the brain, namely the lateral ventricles/rostral migratory stream and the hippocampal

\footnotetext{
*Correspondence to: María Llorens-Martín, Centro de Biología Molecular "Severo Ochoa", Universidad Autónoma de Madrid, campus de Cantoblanco, c/Nicolás Cabrera 1, 28049, Madrid, Spain. Tel.: +34 911964592; E-mail: m.llorens@csic.es.
}

dentate gyrus (DG) [1]. Recent decades have witnessed the increasing relevance of the latter structure. This relevance can be explained by the fact that it participates in the acquisition, processing and consolidation of memory [2]. Moreover, there is solid evidence that the rate of $\mathrm{AHN}$ is sustained in humans during adulthood [3-5]. Furthermore, the hippocampus and the main afferent of this structure, namely the Entorhinal cortex (EC), are severely affected by neurodegenerative diseases in general, and by Alzheimer disease $(\mathrm{AD})$ in particular, which are among the greatest challenges currently facing modern medicine [6]. 
Indeed, growing evidence supports the notion that $\mathrm{AD}$ is a synaptopathy characterized by a generalized lack of neural plasticity in the hippocampus and other related structures [7, 8]. Thus, various therapeutic strategies attempt to preserve brain plasticity in order to prevent or slow down the progression of this disease $[9,10]$. In this regard, adult hippocampal neurogenesis (AHN) contributes to the unique complexity of the hippocampal circuitry, and the continuous addition of new neurons through this process is believed to confer remarkable plasticity to this structure throughout life [11-18], and to increase the cognitive reserve during aging [19]. Moreover, given that numerous external factors, including lifestyle, exert a rapid and multi-directional regulation of the rate of AHN, this process has been referred to as a sensor of information processing requirements [20-27].

In this regard, environmental enrichment (EE) and physical exercise are among the most potent selective and positive regulators of AHN [25, 28-30]. They also exert numerous beneficial effects on hippocampal-dependent memory and preserve brain plasticity throughout life [29, 31-38]. This review article summarizes current evidence supporting the putative therapeutic potential of EE and physical exercise to increase AHN and hippocampal plasticity both under physiological and pathological circumstances, with a special emphasis on neurodegenerative diseases and $\mathrm{AD}$.

\section{REASONS WHY THE ADDITION OF NEW NEURONS TO THE HIPPOCAMPUS IS IMPORTANT}

The hippocampus is a bilateral structure located in the temporal lobes of the brain. It has been considered a "memory gateway" $[39,40]$. It plays key roles in the transition from short-term to long-term memory, and it is crucial for spatial memory and navigation $[2,41$, 42]. The vast diversity of neuronal cell types located in the different hippocampal subfields, together with the presence of complex, multi-directional, intra- and extra-hippocampal neural circuits [43-45], confer this structure unique information-encoding capacity. Indeed, several parallel pathways orchestrate the information flux into and from the hippocampus to other regions of the brain. The hippocampal formation belongs to the limbic system, and it receives afferents from various brain regions, including the EC, the mammillary bodies (MB), the amygdala and the hypothalamus [40]. Once the information has been processed in the hippocampus, it is projected back to the EC via the subiculum. The DG exerts a sparse encoding of memories [46]. Moreover, both pattern separation and pattern completion capacity have been attributed to the main population of neurons present in this structure, namely granule neurons $[11,47]$. Although this topic is not devoid of controversy, the general consensus in the field is that either granule neurons generated during development or those generated as a consequence of adult neurogenesis play differential-sometimes collaborative and other times competitive-roles in information processing [15, 48-50]. In general terms, pattern separation, which consists of producing differentiated outcomes in response to very similar inputs, is facilitated by newborn granule neurons $[11,16,47$, 51-53]. This capacity is conferred by special electrophysiological properties, namely increased intrinsic excitability and a lower activation threshold [54, 55], and by a particular innervation timing [56-61] exhibited by these neurons when they are young and excitable [13, 54, 62]. In contrast, fully mature and developmentally generated granule neurons are believed to contribute to more stable memory storage and to pattern completion, a phenomenon based mostly on generalization processes [47]. Within the hippocampal circuitry, the DG itself participates in two major circuits. The first, named classic trisynaptic hippocampal circuit, includes a projection from the granule neurons to the Cornu ammonis CA3 region [44]. This connection is involved in spatial memory and mood regulation, and it has been extensively explored [63-67]. In addition, Keiko Kohara and Susumu Tonegawa recently described the alternative trisynaptic circuit, in which granule neurons project to the CA2 hippocampal subfield [68]. Subsequently, our group showed that maturing newborn granule neurons also project to this structure following a temporal pattern similar to the one they follow to establish connections with the CA3 field [69]. Whether all newborn granule neurons connect to the CA3 or to the CA2 fields or whether they establish connections to both fields is still a matter of debate since technical difficulties currently prevent scientists from answering this challenging question. However, the field has acknowledged that the connection between the DG and the CA2 field is required for context discrimination and social memory $[70,71]$. The participation of newborn granule neurons in these tasks remains to be fully elucidated. However, previous evidence supports the contribu- 
tion of this cell population to the processing of similar contextual cues [53, 72, 73]. Interestingly, physical exercise selectively increases the number of axonal terminals (named mossy fiber terminals, MFTs) of newborn granule neurons in the CA2 field [69]. This finding may have important consequences for the hippocampal network remodeling that occurs in response to physical exercise and $\mathrm{EE}[74,75]$ and may be related to the selective enhancement of pattern separation capacity exerted by exercise $[32,76]$.

\section{ENVIRONMENTAL ENRICHMENT AND PHYSICAL EXERCISE INCREASE ADULT HIPPOCAMPAL NEUROGENESIS THROUGH THE ACTIVATION OF CONFLUENT PATHWAYS}

Several years ago, three seminal studies were published by Gage's lab. Gerd Kempermann and Henriette van Praag showed that physical exercise and EE increase the proliferation and survival of newborn granule neurons $[25,30,77]$. Their findings have since been replicated by numerous labs working in AHN, and many valuable pieces of information have been added to shape our current knowledge of the regulation of this phenomenon by physical exercise and $\mathrm{EE}$ [24, 28, 78-80]. In addition to increasing proliferation and survival, subsequent technical and methodological refinement has revealed that physical exercise and EE modify almost every single step of AHN [81-84]. These two interventions increase the maturation [30] and the complexity of dendritic arbor morphology of newborn granule neurons [17, $79,82,85-89]$. This increase in maturation is also reflected by the modification of the electrophysiological properties of these neurons [17, 82]. Moreover, an observation of particular relevance for research on neurodegenerative diseases is that physical exercise and EE increase the synaptic integration of these cells [61, 69, 90-92]. Indeed, retrograde tracing experiments have revealed that these two interventions completely rewire the afferent connections of newborn granule neurons [91-93] in a maturational stage-dependent way [91]. These changes are supported by observation of a marked increase in the number and size of dendritic spines $[61,82,94]$ and postsynaptic densities [86], and by the increase in the size of the MFTs in the CA3 and the CA2 regions [69, 95] in these cells after stimulation with either physical exercise or EE.
Whether the neuroprotective effects exerted by physical exercise and EE on newborn granule neuron maturation in wildtype animals can be exploited as a therapeutic strategy to counteract the hippocampal alterations observed in AD models and patients will be further discussed in subsequent sections of this article. In this regard, several aspects of the neuroprotective actions of physical exercise and EE are often neglected in the literature. For instance, gender- [96-99], inter-individual- [100, 101], housing condition- [102], age- [103-106], and regional[107-110] dependent differences in the effects of EE and physical exercise have been reported. These data should be taken into account when prescribing these interventions as co-adjuvant therapies to patients, since they may limit the success not only of these but also of other therapies prescribed to the same individuals.

Regarding the molecular mechanisms mediating the effects of physical activity or EE on AHN and cognition, these two strategies differ in some aspects [111-116]. In fact, EE encompasses a multi-factor protocol that includes, but is not limited to, voluntary physical activity. In addition to the physical activity component, $\mathrm{EE}$ is also characterized by increased social interaction and continuous cognitive stimulation. These additional aspects of EE may account for some of the aforementioned differences and for the broader actions of EE in comparison to those of physical exercise. Indeed, even very short EE interventions can elicit metaplastic events in the hippocampus [36, 117, 118].

Regardless of the variable degree of overlap between the mechanisms of action of EE and physical activity, it is widely accepted that these two stimuli entirely remodel the transcriptome of the hippocampal milieu [119] and thus create a novel, neuroprotective, and enriched scenario in which newborn granule neurons grow and mature. Physical exercise and EE modify the secretion pattern of growth factors [120-125], neurotransmitters [122, 126, 127] and neuromodulators [128]. Moreover, the structure of perineuronal nets and the extracellular matrix is remodeled [71, 129], and blood influx is finely regulated through changes in microvasculature and endothelial cells $[130,131]$. In addition, these two interventions exert a complex modulation of neuroinflammation [132-137] and oxidative stress [114, 138] and modify the behavior of two cell populations that tightly regulate the maturation of newborn granule neurons, namely astrocytes and microglial cells [59, 139, 140]. Moreover, EE and physical exercise have 
an impact on diverse hippocampal neurotransmission systems [36, 61, 91, 141, 142], including the expression and properties of glutamate receptor subunits [143-147], synaptic adaptor proteins [148-151], and other molecules related to plasticity [152-156].

Thus, through a shift in the environment in which newborn neurons are born $[145,157,158]$, physical exercise and EE positively modulate the neurogenic permissiveness of the subgranular zone (SGZ) and facilitate the incorporation of highly plastic, newly generated, maturing granule neurons into the trisynaptic circuit. Consequently, these interventions improve hippocampal-dependent learning $[159,160]$ and pattern separation ability in mice [32] and humans alike [76, 161]. Therefore, EE and exercise converge at a crossroad: a profound and multi-faceted increase in hippocampal plasticity [36, 74, 75, 142]. Given that many neurodegenerative diseases are characterized by a generalized lack of neural plasticity, the therapeutic potential of making certain lifestyle changes, such as increasing the level of physical activity, has become the cornerstone of several nonpharmacologic strategies aimed to slow down or prevent the progression of these diseases.

\section{MULTIPLE STAGES OF ADULT HIPPOCAMPAL NEUROGENESIS ARE AFFECTED BY NEURODEGENERATIVE DISORDERS}

Classical approaches to study neurodegenerative diseases include the use of transgenic animal models that mimic specific pathological aspects of neurodegeneration. In the case of $\mathrm{AD}$, these animals are often engineered to carry mutations in specific genes that encode proteins such as Amyloid- $\beta$ precursor protein (APP) [162, 163], Tau [164], or Presenilin I and II [165]. These mutations have been described in families that exhibit an increased risk and frequency of AD cases. However, as familial cases of the disease account for a negligible proportion of the total number of AD cases, other animal models have been engineered to mirror the increase in the activity of several molecules involved in the pathogenesis of the condition. Such is the case of glycogen synthase kinase $3 \beta$-overexpressing mice (GSK-3 $\beta$-OE mice) $[166,167]$. Other animal models mimic pathological aspects related to inflammation and the propagation of Amyloid- $\beta$ [168] and Tau [169, 170], or exhibit accelerated aging [171]. Although there is no current evidence that alterations in AHN are the primary cause of $\mathrm{AD}$, most of these models show alterations in this process [9, 172, 173]. In this regard, alterations in the proliferation of progenitor cells, survival of newly generated neurons or exhaustion of the radial glia-like cell pool have been reported in a number of animal models of $\mathrm{AD}[9,173]$, and importantly in patients with this disease [174].

In addition, several years ago our group described that granule neurons in $\mathrm{AD}$ patients exhibit a profound morphological alteration, and that this phenotype is identical to that described in a murine model of the disease that overexpresses GSK-3 $\beta$ in these cells, namely GSK-3 $\beta-O E$ mice [86]. Both in wildtype animals and control subjects, the classical morphology of granule neurons is featured by the presence of a single primary apical dendrite emerging from the soma. This dendrite is increasingly branched as the dendritic tree goes through the molecular layer (ML) of the DG, thus forming a "Y" shape [175]. However, in AD patients and in GSK-3 $\beta-O E$ mice, these neurons exhibit a phenotype we named "V-shape", due to the presence of several primary apical dendrites emerging from the soma and that are poorly branched in the ML. [86, 176]. Interestingly, granule neurons exhibit an extremely similar morphological phenotype under a variety of pathological situations, such as seizures [177], stress [178] and inflammation [179, 180], and in other models of neurodegenerative conditions, such as Parkinson's disease [181]. Further studies are needed to determine whether shared mechanisms trigger the appearance of this morphological phenotype in response to the previously mentioned insults. However, of note, all these circumstances converge in an increase in GSK-3 $\beta$ activity [182-184]. In fact, we demonstrated that the cell-autonomous expression of GSK-3 $\beta$ in newborn granule neurons is sufficient to replicate the morphological phenotype observed in the transgenic animal model and in patients [185, 186]. Given this finding, this kinase emerges as key component in the regulation of the morphology of this cell population.

In addition to the morphological alterations observed in the granule neurons of GSK-3 $\beta$-OE mice and $\mathrm{AD}$ patients, there is a profound impairment in the connectivity of these cells $[86,187]$. In this regard, GSK-3 $\beta$ plays key roles in the synaptic compartment $[188,189]$. Although the physiological function of this kinase and that of its main downstream target Tau are required for the proper functioning of the glutamatergic synapse, the aberrant phosphorylation of Tau or the overexpression of GSK-3 $\beta$ trigger the endocytosis of glutamate receptors and the dis- 
appearance of synapses [86, 190-192]. Whether the aforementioned alterations can be ameliorated by non-pharmacological interventions such as physical exercise or EE will be further discussed in the next sections of this review article.

\section{EFFECTS OF PHYSICAL EXERCISE AND ENVIRONMENTAL ENRICHMENT IN ALZHEIMER DISEASE}

Physical activity and EE trigger an AHNdependent increase in long-term memory [193]. Moreover, these interventions exert a variety of beneficial neurological effects [38, 194, 195], including a reduction in anxiety and depression [98, 196-198], an improvement of pattern separation capacity in healthy subjects [76, 161], and an amelioration of cognitive deficits in patients with mild cognitive impairment [199] and in AD patients [200]. Moreover, physical exercise and EE reduce neuroinflammation [132, 201] and oxidative stress [144, 202, 203]. These and other beneficial effects are observed in a wide variety of physiological and pathological conditions, such as in aging [35, 204-210], traumatic brain injury $[132,211,212]$, ischemia [123, 213-219], brain lesions [198, 220, 221], acute and chronic stress [222-225], maternal deprivation [226, 227], cranial irradiation [228, 229], bacterial infection [133, 230], inflammation [231, 232], diabetes and metabolic syndrome [233-235], seizures [236-238], exposure to toxic molecules [239-243], and chemotherapy [244]. In addition, physical exercise and EE improve cognition in other neurological conditions such as schizophrenia [245, 246], autism [247], post-traumatic stress disorder [248], developmental alterations [249, 250], Angelman [251], Rett [252], Fragile X [253] and Down [254-257] syndromes, vascular dementia [258], and Huntington's disease [259, 260]. Moreover, despite the unknown nature of the etiology of $\mathrm{AD}$, the general consensus in the field points to lifestyle as an important factor able to decrease the risk and/or halt the progression of the disease [38, 158].

In this regard, the neurotrophic hypothesis of the mechanisms of action of physical exercise [194, 261-264] postulates that the increase in the levels of neurotrophins and growth factors triggered by this stimulus are responsible for its beneficial effects on brain and cognition [265-267]. In fact, previous reports demonstrate that the effects of physical exercise and EE on cognition are dependent on the circulating levels of the insulin-like growth factor I
(IGF-I) [268-270], brain-derived neurotrophic factor (BDNF) [266, 271], and vascular-endothelial growth factor (VEGF) [272]. Importantly, the molecular pathways activated by these and other growth factors converge to inhibit GSK-3 $\beta$ through phosphorylation of Serine9 [273-275]. Thus, the signaling cascades activated by growth factors could potentially ameliorate some of the pathological consequences of $\mathrm{AD}$, namely the over-activation of GSK-3 $\beta$ and the hyperphosphorylation of Tau. Importantly, these two phenomena are among the most potent inhibitors of AHN [180, 274, 276-278], whereas growth factors are potent positive regulators of this process $[263,279]$. Thus, when addressing why AHN, despite not being the primary cause of $\mathrm{AD}$, is so dramatically impaired in this disease, it should be taken into account that most neurodegenerative diseases are characterized by a marked decrease in the levels of neurotrophins [280]. It has been proposed that, by increasing the levels of circulating neurotrophic factors, physical exercise can serve as a neuroprotective strategy for neurodegenerative conditions [262].

Despite the clear benefits of physical activity on humans, testing the efficacy of physical exercise and $\mathrm{EE}$ to alleviate the pathological features of $\mathrm{AD}$ in animal models has rendered complex and sometimes contradictory results [281, 282]. As pointed out by several authors, differences in exercise protocols, gender, housing conditions and mouse strains can account for these discrepancies [113, 283, 284]. With regard to memory impairments and neuropathological features, numerous bodies of evidence point to the neuroprotective or even therapeutic potential of these interventions [171, 225, 285-287], whereas other studies report no improvement in memory tasks after the exposure of certain $\mathrm{AD}$ animal models to exercise [281, 288]. In agreement, these interventions do not appear to recover all the aspects of AHN affected by the progression of $\mathrm{AD}[282,289]$, although most of the studies support the neuroprotective potential of exercise and EE to sustain increased levels of AHN in models of this disease [103, 225, 287, 290-294]. Nevertheless, some reports also provide evidence of a slight discrepancy between the effects of physical exercise and EE on AHN and on cognition [282, 293, 295].

Over the last decade we have extensively characterized the dynamics of AHN in GSK-3 $\beta$-OE mice in response to physical exercise and EE. One of the most outstanding alterations in the newborn neurons of these mice, namely their aberrant morphology, is completely reversed when these animals are exposed 
to voluntary running for 2 weeks or to EE for 4 weeks respectively [86, 176, 185]. However, we found that the impaired connectivity of these neurons was not normalized by these non-pharmacological strategies $[86,185]$. In addition, a mouse model that lacks Tau [296] exhibits a marked decrease in the number and size of synaptic contacts in the most distal part of the dendritic tree, and these alterations are not reversed by EE [95]. Further studies are needed to address why newborn neurons of these animal models are not responsive to the stimulatory actions of physical exercise and EE. However, it is known that the outer segment of the dendritic tree of granule neurons receives most of the afferent information from the EC under physiological conditions, and Zhao and Gage elegantly demonstrated several years ago that synaptogenesis in this domain of the dendritic tree of newborn granule neurons is selectively regulated by environment in a very particular way. In this regard, spatial cues related to the size of the living environment selectively increase spinogenesis in this region [297]. The incapacity of newborn granule neurons of certain $\mathrm{AD}$ animal models to show an increase in synaptogenesis in response to physical exercise or EE can be explained by two alternative mechanisms. On the one hand, this incapacity may reflect a specific synaptic role played by GSK-3 $\beta$ or Tau in encoding the aforementioned type of spatial information, which increases distal synaptogenesis under physiological conditions. On the other hand, the dysregulation of GSK-3 $\beta$ activity or the absence of Tau may alter the plasticity of dendritic microtubules, thereby impeding the correct transport of synaptic proteins to the most distal parts of the dendritic tree. Further studies are needed to determine whether this insensitivity is a particular feature of these animal models or whether it represents a common mechanism that may limit the effectiveness of physical activity to potentiate the synaptic integration of newborn granule neurons in AD models and patients.

A final crucial consideration that affects not only $\mathrm{AD}$ but many other neurodegenerative diseases is that the first "invisible" silent alterations occur several decades before the appearance of the first clinical manifestation of the disease [298, 299]. Deciphering the exact time at which preventive strategies would have a greater impact is currently impeded by the lack of full elucidation of the etiology of these conditions. Nevertheless, previous evidence suggests that the rate of AHN is sustained throughout life in humans [3-5]. Thus, it is postulated that the contri- bution of this phenomenon to the neurogenic reserve [19] is maintained during adulthood. Nevertheless, in the unlikely event that humans experience a decrease in the rate of AHN similar to that observed in rodents, physical exercise would be expected to lead to a robust improvement of AHN at all ages. This notion is supported by previous lines of evidence in mice demonstrating that physical exercise enhances AHN both in healthy and AD mice and that this increase is quantitatively greater than that detected in young mice [206, 300, 301]. Thus, strategies designed to increase AHN in young, aged, healthy or diseased individuals is expected to greatly contribute to boosting neurogenic and cognitive reserves both during physiological and pathological ageing.

\section{CONCLUDING REMARKS AND FURTHER DIRECTIONS}

Despite the unknown nature of numerous neurodegenerative diseases, including $\mathrm{AD}$, a common feature of their progression is a generalized lack of neural plasticity in certain susceptible brain regions. The hippocampus and its main afferent structure, namely the EC, are two of the first areas affected by $\mathrm{AD}$ progression. In these brain regions, neurons exhibit morphological alterations, as well as a marked decrease in their afferent and efferent connectivity. The continuous addition of new neurons to the trisynaptic circuit serves as an endless source of novel synaptic connections that can be finely tuned in response to changing environments or to changing information processing requirements. In this regard, AHN has emerged as an alternative strategy to preserve neuroplasticity in the hippocampus. The observation that clinically and economically affordable, non-pharmacological interventions, such as increasing the level of physical activity, enhance the rate of $\mathrm{AHN}$ and improve memory has put them in the spotlight as strategies to improve brain health and to keep hippocampal plasticity at high levels throughout life. Given that neurodegenerative diseases are multi-faceted pathologies with slow progression and they involve numerous non-cell autonomous effects, such as inflammation and neurovascular alterations, promising therapies often lead to nothing. Moreover, data obtained from animal models of the disease suggest that cell-autonomous effects derived from the deregulation of the activity of certain toxic proteins limit per se the beneficial effects of physical exercise and EE on brain health. Further studies 
should address whether the combination of these nonpharmacological strategies and targeted drugs against deregulated pathological proteins can effectively prevent, slow down, ameliorate the symptoms or even vanquish these as yet incurable and devastating diseases.

\section{ACKNOWLEDGMENTS}

Some of the studies reported in this Review were supported by the Spanish Ministry of Economy and Competitiveness (SAF-2017-82185-R and RYC-2015-171899); the Alzheimer's Association (2015-NIRG-340709 and AARG-17-528125) and the Association for Frontotemporal Degeneration (2016 Basic Science Pilot Grant Award).

\section{CONFLICT OF INTEREST}

The author declares no conflict of interest.

\section{REFERENCES}

[1] Altman J, Das GD. Autoradiographic and histological evidence of postnatal hippocampal neurogenesis in rats. J Comp Neurol. 1965;124(3):319-35.

[2] Moser MB, Moser EI. Distributed encoding and retrieval of spatial memory in the hippocampus. J Neurosci. 1998;18(18):7535-42.

[3] Eriksson PS, Perfilieva E, Bjork-Eriksson T, Alborn AM, Nordborg C, Peterson DA, et al. Neurogenesis in the adult human hippocampus. Nat Med. 1998;4(11):1313-7.

[4] Knoth R, Singec I, Ditter M, Pantazis G, Capetian P, Meyer $\mathrm{RP}$, et al. Murine features of neurogenesis in the human hippocampus across the lifespan from 0 to 100 years. PLoS one. 2010;5(1):e8809.

[5] Spalding KL, Bergmann O, Alkass K, Bernard S, Salehpour M, Huttner HB, et al. Dynamics of hippocampal neurogenesis in adult humans. Cell. 2013;153(6):1219-27.

[6] Hyman BT, Van Hoesen GW, Kromer LJ, Damasio AR. Perforant pathway changes and the memory impairment of Alzheimer's disease. Ann Neurol. 1986;20(4):472-81.

[7] Coleman P, Federoff H, Kurlan R. A focus on the synapse for neuroprotection in Alzheimer disease and other dementias. Neurology. 2004;63(7):1155-62.

[8] Nelson PG. Activity-dependent synapse modulation and the pathogenesis of Alzheimer disease. Curr Alzheimer Res. 2005;2(5):497-506.

[9] Lazarov O, Mattson MP, Peterson DA, Pimplikar SW, van Praag $H$. When neurogenesis encounters aging and disease. Trends Neurosci. 2010;33(12):569-79.

[10] Mu Y, Gage FH. Adult hippocampal neurogenesis and its role in Alzheimer's disease. Mol Neurodegener. 2011;6:85.

[11] Aimone JB, Wiles J, Gage FH. Potential role for adult neurogenesis in the encoding of time in new memories. Nat Neurosci. 2006;9(6):723-7.
[12] Deng W, Aimone JB, Gage FH. New neurons and new memories: How does adult hippocampal neurogenesis affect learning and memory? Nat Rev Neurosci. 2010;11(5):339-50

[13] Deng W, Saxe MD, Gallina IS, Gage FH. Adult-born hippocampal dentate granule cells undergoing maturation modulate learning and memory in the brain. J Neurosci. 2009;29(43):13532-42.

[14] Gage FH. Structural plasticity of the adult brain. Dialogues Clin Neurosci. 2004;6(2):135-41.

[15] Goncalves JT, Schafer ST, Gage FH. Adult Neurogenesis in the Hippocampus: From Stem Cells to Behavior. Cell. 2016;167(4):897-914.

[16] Johnston ST, Shtrahman M, Parylak S, Goncalves JT, Gage FH. Paradox of pattern separation and adult neurogenesis: A dual role for new neurons balancing memory resolution and robustness. Neurobiol Learn Mem. 2016;129: 60-8.

[17] van Praag H, Schinder AF, Christie BR, Toni N, Palmer TD, Gage FH. Functional neurogenesis in the adult hippocampus. Nature. 2002;415(6875):1030-4.

[18] Trinchero MF, Buttner KA, Sulkes Cuevas JN, Temprana SG, Fontanet PA, Monzon-Salinas MC, et al. High plasticity of new granule cells in the aging hippocampus. Cell Reports. 2017;21(5):1129-39.

[19] Kempermann G. The neurogenic reserve hypothesis: What is adult hippocampal neurogenesis good for? Trends Neurosci. 2008;31(4):163-9.

[20] Ben Rokia-Mille S, Tinette S, Engler G, Arthaud L, Tares S, Robichon A. Continued neurogenesis in adult Drosophila as a mechanism for recruiting environmental cue-dependent variants. PLoS One. 2008;3(6):e2395.

[21] Kempermann G, Wiskott L, Gage FH. Functional significance of adult neurogenesis. Curr Opin Neurobiol. 2004;14(2):186-91.

[22] Gage FH. Molecular and cellular mechanisms contributing to the regulation, proliferation and differentiation of neural stem cells in the adult dentate gyrus. Keio J Med. 2010;59(3):79-83.

[23] Kempermann G, Chesler EJ, Lu L, Williams RW, Gage FH. Natural variation and genetic covariance in adult hippocampal neurogenesis. Proc Natl Acad Sci U S A. 2006;103(3):780-5.

[24] Kempermann G, Gage FH. Experience-dependent regulation of adult hippocampal neurogenesis: Effects of long-term stimulation and stimulus withdrawal. Hippocampus. 1999;9(3):321-32.

[25] Kempermann G, Kuhn HG, Gage FH. More hippocampal neurons in adult mice living in an enriched environment. Nature. 1997;386(6624):493-5.

[26] Kempermann G, van Praag H, Gage FH. Activitydependent regulation of neuronal plasticity and self repair. Prog Brain Res. 2000;127:35-48.

[27] Ma DK, Marchetto MC, Guo JU, Ming GL, Gage FH, Song $\mathrm{H}$. Epigenetic choreographers of neurogenesis in the adult mammalian brain. Nat Neurosci. 2010;13(11):1338-44.

[28] Fabel K, Wolf SA, Ehninger D, Babu H, Leal-Galicia P, Kempermann G. Additive effects of physical exercise and environmental enrichment on adult hippocampal neurogenesis in mice. Front Neurosci. 2009;3:50.

[29] van Praag H. Exercise and the brain: Something to chew on. Trends Neurosci. 2009;32(5):283-90.

[30] van Praag H, Kempermann G, Gage FH. Running increases cell proliferation and neurogenesis in the adult mouse dentate gyrus. Nat Neurosci. 1999;2(3):266-70. 
[31] Clemenson GD, Stark CE. Virtual environmental enrichment through video games improves hippocampalassociated memory. J Neurosci. 2015;35(49):1611625.

[32] Creer DJ, Romberg C, Saksida LM, van Praag H, Bussey TJ. Running enhances spatial pattern separation in mice. Proc Natl Acad Sci U S A. 2010;107(5):2367-72.

[33] van Praag H, Shubert T, Zhao C, Gage FH. Exercise enhances learning and hippocampal neurogenesis in aged mice. J Neurosci. 2005;25(38):8680-5.

[34] Cooper C, Moon HY, van Praag H. On the run for hippocampal plasticity. Cold Spring Harb Perspect Med. 2017.

[35] Cortese GP, Olin A, O'Riordan K, Hullinger R, Burger C. Environmental enrichment improves hippocampal function in aged rats by enhancing learning and memory, LTP, and mGluR5-Homer1c activity. Neurobiol Aging. 2017;63:1-11.

[36] Eckert MJ, Abraham WC. Effects of environmental enrichment exposure on synaptic transmission and plasticity in the hippocampus. Curr Top Behav Neurosci. 2013;15:165-87.

[37] Iso H, Simoda S, Matsuyama T. Environmental change during postnatal development alters behaviour, cognitions and neurogenesis of mice. Behav Brain Res. 2007;179(1):90-8.

[38] Cotman CW, Berchtold NC. Exercise: A behavioral intervention to enhance brain health and plasticity. Trends Neurosci. 2002;25(6):295-301.

[39] Henke K, Kroll NE, Behniea H, Amaral DG, Miller $\mathrm{MB}$, Rafal R, et al. Memory lost and regained following bilateral hippocampal damage. J Cogn Neurosci. 1999;11(6):682-97.

[40] Suzuki WA, Amaral DG. Functional neuroanatomy of the medial temporal lobe memory system. Cortex. 2004;40(1):220-2.

[41] Andersen P, Moser E, Moser MB, Trommald M. Cellular correlates to spatial learning in the rat hippocampus. J Physiol Paris. 1996;90(5-6):349.

[42] Ramirez S, Liu X, Lin PA, Suh J, Pignatelli M, Redondo $\mathrm{RL}$, et al. Creating a false memory in the hippocampus. Science. 2013;341(6144):387-91.

[43] Li Y, Stam FJ, Aimone JB, Goulding M, Callaway EM, Gage FH. Molecular layer perforant path-associated cells contribute to feed-forward inhibition in the adult dentate gyrus. Proc Natl Acad Sci U S A. 2013;110(22): 9106-11.

[44] Amaral DG. A Golgi study of cell types in the hilar region of the hippocampus in the rat. J Comp Neurol. 1978;182(4 Pt 2):851-914.

[45] Amaral DG, Kondo H, Lavenex P. An analysis of entorhinal cortex projections to the dentate gyrus, hippocampus, and subiculum of the neonatal macaque monkey. J Comp Neurol. 2014;522(7):1485-505.

[46] Wiskott L, Rasch MJ, Kempermann G. A functional hypothesis for adult hippocampal neurogenesis: Avoidance of catastrophic interference in the dentate gyrus. Hippocampus. 2006;16(3):329-43.

[47] Nakashiba T, Cushman JD, Pelkey KA, Renaudineau S, Buhl DL, McHugh TJ, et al. Young dentate granule cells mediate pattern separation, whereas old granule cells facilitate pattern completion. Cell. 2012;149(1):188-201.

[48] Aimone JB, Wiles J, Gage FH. Computational influence of adult neurogenesis on memory encoding. Neuron. 2009;61(2):187-202.
[49] Rangel LM, Quinn LK, Chiba AA, Gage FH, Aimone JB A hypothesis for temporal coding of young and mature granule cells. Front Neurosci. 2013;7:75.

[50] McAvoy KM, Scobie KN, Berger S, Russo C, Guo N, Decharatanachart $\mathrm{P}$, et al. Modulating neuronal competition dynamics in the dentate gyrus to rejuvenate aging memory circuits. Neuron. 2016;91(6):1356-73.

[51] Clelland CD, Choi M, Romberg C, Clemenson Jr GD, Fragniere A, Tyers $\mathrm{P}$, et al. A functional role for adult hippocampal neurogenesis in spatial pattern separation. Science. 2009;325(5937):210-3.

[52] Jessberger S, Clark RE, Broadbent NJ, Clemenson Jr GD, Consiglio A, Lie DC, et al. Dentate gyrus-specific knockdown of adult neurogenesis impairs spatial and object recognition memory in adult rats. Learn Mem. 2009;16(2):147-54.

[53] Sahay A, Scobie KN, Hill AS, O'Carroll CM, Kheirbek MA, Burghardt NS, et al. Increasing adult hippocampal neurogenesis is sufficient to improve pattern separation. Nature. 2011;472(7344):466-70.

[54] Schmidt-Hieber C, Jonas P, Bischofberger J. Enhanced synaptic plasticity in newly generated granule cells of the adult hippocampus. Nature. 2004;429(6988):184-7.

[55] Marin-Burgin A, Mongiat LA, Pardi MB, Schinder AF. Unique processing during a period of high excitation/inhibition balance in adult-born neurons. Science. 2012;335(6073):1238-42.

[56] Overstreet Wadiche L, Bromberg DA, Bensen AL, Westbrook GL. GABAergic signaling to newborn neurons in dentate gyrus. J Neurophysiol. 2005;94(6):4528-32.

[57] Piatti VC, Davies-Sala MG, Esposito MS, Mongiat LA, Trinchero MF, Schinder AF. The timing for neuronal maturation in the adult hippocampus is modulated by local network activity. J Neurosci. 2011;31(21):7715-28.

[58] Laplagne DA, Kamienkowski JE, Esposito MS, Piatti VC, Zhao C, Gage FH, et al. Similar GABAergic inputs in dentate granule cells born during embryonic and adult neurogenesis. Eur J Neurosci. 2007;25(10):2973-81.

[59] Krzisch M, Temprana SG, Mongiat LA, Armida J, Schmutz V, Virtanen MA, et al. Pre-existing astrocytes form functional perisynaptic processes on neurons generated in the adult hippocampus. Brain Struct Funct. 2015;220(4):2027-42.

[60] Ganguly K, Schinder AF, Wong ST, Poo M. GABA itself promotes the developmental switch of neuronal GABAergic responses from excitation to inhibition. Cell. 2001;105(4):521-32.

[61] Alvarez DD, Giacomini D, Yang SM, Trinchero MF, Temprana SG, Buttner KA, et al. A disynaptic feedback network activated by experience promotes the integration of new granule cells. Science. 2016;354(6311):459-65.

[62] Bischofberger J. Young and excitable: New neurons in memory networks. Nature Neuroscience. 2007;10(3): 273-5.

[63] Zhang B, Chuang KH, Tjio C, Chen WC, Sheu FS, Routtenberg A. Spatial memory training induces morphological changes detected by manganese-enhanced MRI in the hippocampal CA3 mossy fiber terminal zone. Neuroimage. 2016;128:227-37.

[64] Routtenberg A. Adult learning and remodeling of hippocampal mossy fibers: Unheralded participant in circuitry for long-lasting spatial memory. Hippocampus. 2010;20(1):44-5.

[65] Ramirez-Amaya V, Balderas I, Sandoval J, Escobar ML, Bermudez-Rattoni F. Spatial long-term memory 
is related to mossy fiber synaptogenesis. J Neurosci. 2001;21(18):7340-8.

[66] Lassalle JM, Bataille T, Halley H. Reversible inactivation of the hippocampal mossy fiber synapses in mice impairs spatial learning, but neither consolidation nor memory retrieval, in the Morris navigation task. Neurobiol Learn Mem. 2000;73(3):243-57.

[67] Crusio WE, Schwegler H, Brust I. Covariations between hippocampal mossy fibres and working and reference memory in spatial and non-spatial radial maze tasks in mice. Eur J Neurosci. 1993;5(10):1413-20.

[68] Kohara K, Pignatelli M, Rivest AJ, Jung HY, Kitamura T, Suh J, et al. Cell type-specific genetic and optogenetic tools reveal hippocampal CA2 circuits. Nat Neurosci. 2014;17(2):269-79.

[69] Llorens-Martin M, Jurado-Arjona J, Avila J, Hernandez F. Novel connection between newborn granule neurons and the hippocampal CA2 field. Exp Neurol. 2015;263: 285-92.

[70] Leroy F, Brann DH, Meira T, Siegelbaum SA. Inputtiming-dependent plasticity in the hippocampal CA2 region and its potential role in social memory. Neuron. 2017;95(5):1089-102 e5.

[71] Alexander GM, Farris S, Pirone JR, Zheng C, Colgin LL, Dudek SM. Social and novel contexts modify hippocampal CA2 representations of space. Nat Commun. 2016;7:10300.

[72] Dupret D, Revest JM, Koehl M, Ichas F, De Giorgi F, Costet P, et al. Spatial relational memory requires hippocampal adult neurogenesis. PLoS One. 2008;3(4):e1959.

[73] Opendak M, Offit L, Monari P, Schoenfeld TJ, Sonti AN, Cameron HA, et al. Lasting Adaptations in Social Behavior Produced by Social Disruption and Inhibition of Adult Neurogenesis. J Neurosci. 2016;36(26):7027-38.

[74] Hirase H, Shinohara Y. Transformation of cortical and hippocampal neural circuit by environmental enrichment. Neuroscience. 2014;280:282-98.

[75] Vivar C, van Praag H. Running changes the brain: The long and the short of it. Physiology (Bethesda). 2017;32(6):410-24.

[76] Suwabe K, Hyodo K, Byun K, Ochi G, Fukuie T, Shimizu $\mathrm{T}$, et al. Aerobic fitness associates with mnemonic discrimination as a mediator of physical activity effects: Evidence for memory flexibility in young adults. Sci Rep. 2017;7(1):5140.

[77] van Praag H, Christie BR, Sejnowski TJ, Gage FH. Running enhances neurogenesis, learning, and longterm potentiation in mice. Proc Natl Acad Sci U S A. 1999;96(23):13427-31.

[78] Brown J, Cooper-Kuhn CM, Kempermann G, Van Praag $\mathrm{H}$, Winkler J, Gage FH, et al. Enriched environment and physical activity stimulate hippocampal but not olfactory bulb neurogenesis. Eur J Neurosci. 2003;17(10):2042-6.

[79] Glasper ER, Llorens-Martin MV, Leuner B, Gould E, Trejo JL. Blockade of insulin-like growth factor-I has complex effects on structural plasticity in the hippocampus. Hippocampus. 2010;20(6):706-12.

[80] Kobilo T, Yuan C, van Praag H. Endurance factors improve hippocampal neurogenesis and spatial memory in mice. Learn Mem. 2011;18(2):103-7.

[81] Barkho BZ, Song H, Aimone JB, Smrt RD, Kuwabara T, Nakashima K, et al. Identification of astrocyte-expressed factors that modulate neural stem/progenitor cell differentiation. Stem Cells Dev. 2006;15(3):407-21.
[82] Zhao C, Teng EM, Summers Jr RG, Ming GL, Gage FH. Distinct morphological stages of dentate granule neuron maturation in the adult mouse hippocampus. J Neurosci. 2006;26(1):3-11.

[83] Gregoire CA, Bonenfant D, Le Nguyen A, Aumont A, Fernandes KJ. Untangling the influences of voluntary running, environmental complexity, social housing and stress on adult hippocampal neurogenesis. PLoS One. 2014;9(1):e86237.

[84] Liu N, He S, Yu X. Early natural stimulation through environmental enrichment accelerates neuronal development in the mouse dentate gyrus. PLoS One. 2012;7(1):e30803.

[85] Darmopil S, Petanjek Z, Mohammed AH, Bogdanovic N. Environmental enrichment alters dentate granule cell morphology in oldest-old rat. J Cell Mol Med. 2009;13(8B):1845-56.

[86] Llorens-Martin M, Fuster-Matanzo A, Teixeira CM, Jurado-Arjona J, Ulloa F, Defelipe J, et al. GSK3beta overexpression causes reversible alterations on postsynaptic densities and dendritic morphology of hippocampal granule neurons in vivo. Molecular Psychiatry. 2013;18(4):451-60.

[87] Dostes S, Dubreucq S, Ladeveze E, Marsicano G, Abrous $\mathrm{DN}$, Chaouloff F, et al. Running per se stimulates the dendritic arbor of newborn dentate granule cells in mouse hippocampus in a duration-dependent manner. Hippocampus. 2016;26(3):282-8.

[88] Faherty CJ, Kerley D, Smeyne RJ. A Golgi-Cox morphological analysis of neuronal changes induced by environmental enrichment. Brain Res Dev Brain Res. 2003;141(1-2):55-61.

[89] Tronel S, Fabre A, Charrier V, Oliet SH, Gage FH, Abrous DN. Spatial learning sculpts the dendritic arbor of adultborn hippocampal neurons. Proc Natl Acad Sci U S A. 2010;107(17):7963-8.

[90] Artola A, von Frijtag JC, Fermont PC, Gispen WH, Schrama LH, Kamal A, et al. Long-lasting modulation of the induction of LTD and LTP in rat hippocampal CA1 by behavioural stress and environmental enrichment. Eur J Neurosci. 2006;23(1):261-72.

[91] Sah N, Peterson BD, Lubejko ST, Vivar C, van Praag H. Running reorganizes the circuitry of one-week-old adultborn hippocampal neurons. Sci Rep. 2017;7(1):10903.

[92] Vivar C, Peterson BD, van Praag H. Running rewires the neuronal network of adult-born dentate granule cells. Neuroimage. 2016;131:29-41.

[93] Bergami M, Masserdotti G, Temprana SG, Motori E, Eriksson TM, Gobel J, et al. A critical period for experience-dependent remodeling of adult-born neuron connectivity. Neuron. 2015;85(4):710-7.

[94] Berman RF, Hannigan JH, Sperry MA, Zajac CS. Prenatal alcohol exposure and the effects of environmental enrichment on hippocampal dendritic spine density. Alcohol. 1996;13(2):209-16.

[95] Pallas-Bazarra N, Jurado-Arjona J, Navarrete M, Esteban JA, Hernandez F, Avila J, et al. Novel function of Tau in regulating the effects of external stimuli on adult hippocampal neurogenesis. The EMBO Journal. 2016;35(13):1417-36.

[96] Lin EJ, Choi E, Liu X, Martin A, During MJ. Environmental enrichment exerts sex-specific effects on emotionality in C57BL/6J mice. Behav Brain Res. 2011;216(1): 349-57.

[97] Marlatt MW, Potter MC, Lucassen PJ, van Praag H. Running throughout middle-age improves memory function, 
hippocampal neurogenesis, and BDNF levels in female C57BL/6J mice. Dev Neurobiol. 2012;72(6):943-52.

[98] Connors EJ, Shaik AN, Migliore MM, Kentner AC. Environmental enrichment mitigates the sex-specific effects of gestational inflammation on social engagement and the hypothalamic pituitary adrenal axis-feedback system. Brain Behav Immun. 2014;42:178-90.

[99] McQuaid RJ, Audet MC, Anisman H. Environmental enrichment in male CD-1 mice promotes aggressive behaviors and elevated corticosterone and brain norepinephrine activity in response to a mild stressor. Stress. 2012;15(3):354-60.

[100] Llorens-Martin M, Torres-Aleman I, Trejo JL. Pronounced individual variation in the response to the stimulatory action of exercise on immature hippocampal neurons. Hippocampus. 2006;16(5):480-90.

[101] Sequeira-Cordero A, Mora-Gallegos A, Cuenca-Berger P, Fornaguera-Trias J. Individual differences in the forced swimming test and the effect of environmental enrichment: Searching for an interaction. Neuroscience. 2014;265: 95-107.

[102] Stranahan AM, Khalil D, Gould E. Social isolation delays the positive effects of running on adult neurogenesis. Nat Neurosci. 2006;9(4):526-33.

[103] Mirochnic S, Wolf S, Staufenbiel M, Kempermann G. Age effects on the regulation of adult hippocampal neurogenesis by physical activity and environmental enrichment in the APP23 mouse model of Alzheimer disease. Hippocampus. 2009;19(10):1008-18.

[104] Mora-Gallegos A, Rojas-Carvajal M, Salas S, SaborioArce A, Fornaguera-Trias J, Brenes JC. Age-dependent effects of environmental enrichment on spatial memory and neurochemistry. Neurobiol Learn Mem. 2015;118: 96-104.

[105] Rizzi S, Bianchi P, Guidi S, Ciani E, Bartesaghi R. Impact of environmental enrichment on neurogenesis in the dentate gyrus during the early postnatal period. Brain Res. 2011;1415:23-33.

[106] Sager T, Kashon M, Krajnak K. Estrogen and environmental enrichment differentially affect neurogenesis, dendritic spine immunolabeling and synaptogenesis in the hippocampus of young and reproductively senescent female rats. Neuroendocrinology. 2017.

[107] Gualtieri F, Bregere C, Laws GC, Armstrong EA, Wylie NJ, Moxham TT, et al. Effects of environmental enrichment on doublecortin and BDNF expression along the dorso-ventral axis of the dentate gyrus. Front Neurosci. 2017;11:488.

[108] Tanti A, Rainer Q, Minier F, Surget A, Belzung C. Differential environmental regulation of neurogenesis along the septo-temporal axis of the hippocampus. Neuropharmacology. 2012;63(3):374-84.

[109] Tanti A, Westphal WP, Girault V, Brizard B, Devers $\mathrm{S}$, Leguisquet AM, et al. Region-dependent and stagespecific effects of stress, environmental enrichment, and antidepressant treatment on hippocampal neurogenesis. Hippocampus. 2013;23(9):797-811.

[110] Zheng J, Jiang YY, Xu LC, Ma LY, Liu FY, Cui $\mathrm{S}$, et al. Adult hippocampal neurogenesis along the dorsoventral axis contributes differentially to environmental enrichment combined with voluntary exercise in alleviating chronic inflammatory pain in mice. J Neurosci. 2017;37(15):4145-57.

[111] Clemenson GD, Lee SW, Deng W, Barrera VR, Iwamoto KS, Fanselow MS, et al. Enrichment rescues contextual discrimination deficit associated with immediate shock. Hippocampus. 2015;25(3):385-92.

[112] Kobilo T, Liu QR, Gandhi K, Mughal M, Shaham $\mathrm{Y}$, van Praag H. Running is the neurogenic and neurotrophic stimulus in environmental enrichment. Learn Mem. 2011;18(9):605-9.

[113] Lambert TJ, Fernandez SM, Frick KM. Different types of environmental enrichment have discrepant effects on spatial memory and synaptophysin levels in female mice. Neurobiol Learn Mem. 2005;83(3):206-16.

[114] Marmol F, Sanchez J, Torres MN, Chamizo VD. Environmental enrichment in the absence of wheel running produces beneficial behavioural and anti-oxidative effects in rats. Behav Processes. 2017;144:66-71.

[115] Olson AK, Eadie BD, Ernst C, Christie BR. Environmental enrichment and voluntary exercise massively increase neurogenesis in the adult hippocampus via dissociable pathways. Hippocampus. 2006;16(3):250-60.

[116] Steiner B, Zurborg S, Horster H, Fabel K, Kempermann G. Differential 24h responsiveness of Prox1-expressing precursor cells in adult hippocampal neurogenesis to physical activity, environmental enrichment, and kainic acid-induced seizures. Neuroscience. 2008;154(2):521-9.

[117] Buschler A, Manahan-Vaughan D. Brief environmental enrichment elicits metaplasticity of hippocampal synaptic potentiation in vivo. Front Behav Neurosci. 2012;6:85.

[118] Stein LR, O'Dell KA, Funatsu M, Zorumski CF, Izumi Y. Short-term environmental enrichment enhances synaptic plasticity in hippocampal slices from aged rats. Neuroscience. 2016;329:294-305.

[119] Keyvani K, Sachser N, Witte OW, Paulus W. Gene expression profiling in the intact and injured brain following environmental enrichment. J Neuropathol Exp Neurol. 2004;63(6):598-609.

[120] Angelucci F, De Bartolo P, Gelfo F, Foti F, Cutuli D, Bossu $\mathrm{P}$, et al. Increased concentrations of nerve growth factor and brain-derived neurotrophic factor in the rat cerebellum after exposure to environmental enrichment. Cerebellum. 2009;8(4):499-506.

[121] Birch AM, McGarry NB, Kelly AM. Short-term environmental enrichment, in the absence of exercise, improves memory, and increases NGF concentration, early neuronal survival, and synaptogenesis in the dentate gyrus in a timedependent manner. Hippocampus. 2013;23(6):437-50.

[122] Chourbaji S, Hortnagl H, Molteni R, Riva MA, Gass P, Hellweg R. The impact of environmental enrichment on sex-specific neurochemical circuitries - effects on brainderived neurotrophic factor and the serotonergic system. Neuroscience. 2012;220:267-76.

[123] Dahlqvist P, Zhao L, Johansson IM, Mattsson B, Johansson BB, Seckl JR, et al. Environmental enrichment alters nerve growth factor-induced gene A and glucocorticoid receptor messenger RNA expression after middle cerebral artery occlusion in rats. Neuroscience. 1999;93(2):527-35.

[124] Torasdotter M, Metsis M, Henriksson BG, Winblad B, Mohammed AH. Environmental enrichment results in higher levels of nerve growth factor mRNA in the rat visual cortex and hippocampus. Behav Brain Res. 1998;93(12):83-90.

[125] Novkovic T, Mittmann T, Manahan-Vaughan D. BDNF contributes to the facilitation of hippocampal synaptic plasticity and learning enabled by environmental enrichment. Hippocampus. 2015;25(1):1-15.

[126] Rasmuson S, Olsson T, Henriksson BG, Kelly PA, Holmes MC, Seckl JR, et al. Environmental enrichment selectively 
increases 5-HT1A receptor mRNA expression and binding in the rat hippocampus. Brain Res Mol Brain Res. 1998;53(1-2):285-90.

[127] Segovia G, Yague AG, Garcia-Verdugo JM, Mora F. Environmental enrichment promotes neurogenesis and changes the extracellular concentrations of glutamate and GABA in the hippocampus of aged rats. Brain Res Bull. 2006;70(1):8-14.

[128] Koehl M, Meerlo P, Gonzales D, Rontal A, Turek FW, Abrous DN. Exercise-induced promotion of hippocampal cell proliferation requires beta-endorphin. FASEB J. 2008;22(7):2253-62.

[129] Nishijima T, Kawakami M, Kita I. A bout of treadmill exercise increases matrix metalloproteinase- 9 activity in the rat hippocampus. Neurosci Lett. 2015;594:144-9.

[130] Ekstrand J, Hellsten J, Tingstrom A. Environmental enrichment, exercise and corticosterone affect endothelial cell proliferation in adult rat hippocampus and prefrontal cortex. Neurosci Lett. 2008;442(3):203-7.

[131] Yuan TF, Ferreira Rocha NB, Paes F, Arias-Carrion O, Machado S, de Sa Filho AS. Neural mechanism of exercise: Neurovascular responses to exercise. CNS \& Neurological Disorders Drug Targets. 2015;14(10): 1304-6.

[132] Briones TL, Woods J, Rogozinska M. Decreased neuroinflammation and increased brain energy homeostasis following environmental enrichment after mild traumatic brain injury is associated with improvement in cognitive function. Acta Neuropathol Commun. 2013;1:57.

[133] Jurgens HA, Johnson RW. Environmental enrichment attenuates hippocampal neuroinflammation and improves cognitive function during influenza infection. Brain Behav Immun. 2012;26(6):1006-16.

[134] Williamson LL, Chao A, Bilbo SD. Environmental enrichment alters glial antigen expression and neuroimmune function in the adult rat hippocampus. Brain Behav Immun. 2012;26(3):500-10.

[135] Beauquis J, Pavia P, Pomilio C, Vinuesa A, Podlutskaya $\mathrm{N}$, Galvan V, et al. Environmental enrichment prevents astroglial pathological changes in the hippocampus of APP transgenic mice, model of Alzheimer's disease. Exp Neurol. 2013;239:28-37.

[136] Soffie M, Hahn K, Terao E, Eclancher F. Behavioural and glial changes in old rats following environmental enrichment. Behav Brain Res. 1999;101(1):37-49.

[137] Viola GG, Rodrigues L, Americo JC, Hansel G, Vargas RS, Biasibetti R, et al. Morphological changes in hippocampal astrocytes induced by environmental enrichment in mice. Brain Res. 2009; 1274:47-54.

[138] Marmol F, Rodriguez CA, Sanchez J, Chamizo VD. Antioxidative effects produced by environmental enrichment in the hippocampus and cerebral cortex of male and female rats. Brain Res. 2015;1613:120-9.

[139] Ehninger D, Kempermann G. Regional effects of wheel running and environmental enrichment on cell genesis and microglia proliferation in the adult murine neocortex. Cereb Cortex. 2003;13(8):845-51.

[140] Sampedro-Piquero P, De Bartolo P, Petrosini L, ZancadaMenendez C, Arias JL, Begega A. Astrocytic plasticity as a possible mediator of the cognitive improvements after environmental enrichment in aged rats. Neurobiol Learn Mem. 2014;114:16-25.

[141] Eckert MJ, Bilkey DK, Abraham WC. Altered plasticity in hippocampal CA1, but not dentate gyrus, following long-term environmental enrichment. J Neurophysiol. 2010;103(6):3320-9.
[142] Farmer J, Zhao X, van Praag H, Wodtke K, Gage FH, Christie BR. Effects of voluntary exercise on synaptic plasticity and gene expression in the dentate gyrus of adult male Sprague-Dawley rats in vivo. Neuroscience. 2004;124(1):71-9.

[143] Andin J, Hallbeck M, Mohammed AH, Marcusson J. Influence of environmental enrichment on steady-state mRNA levels for EAAC1, AMPA1 and NMDA2A receptor subunits in rat hippocampus. Brain Res. 2007;1174:18-27.

[144] Briones TL, Rogozinska M, Woods J. Modulation of ischemia-induced NMDAR1 activation by environmental enrichment decreases oxidative damage. J Neurotrauma. 2011;28(12):2485-92.

[145] Buschler A, Manahan-Vaughan D. Metabotropic glutamate receptor, mGlu5, mediates enhancements of hippocampal long-term potentiation after environmental enrichment in young and old mice. Neuropharmacology. 2017;115:42-50.

[146] Gagne J, Gelinas S, Martinoli MG, Foster TC, Ohayon M, Thompson RF, et al. AMPA receptor properties in adult rat hippocampus following environmental enrichment. Brain Res. 1998;799(1):16-25.

[147] Naka F, Narita N, Okado N, Narita M. Modification of AMPA receptor properties following environmental enrichment. Brain Dev. 2005;27(4):275-8.

[148] Bednarek E, Caroni P. beta-Adducin is required for stable assembly of new synapses and improved memory upon environmental enrichment. Neuron. 2011;69(6):1132-46.

[149] Heinla I, Leidmaa E, Kongi K, Pennert A, Innos J, Nurk $\mathrm{K}$, et al. Gene expression patterns and environmental enrichment-induced effects in the hippocampi of mice suggest importance of Lsamp in plasticity. Front Neurosci. 2015;9:205.

[150] Huang FL, Huang KP, Wu J, Boucheron C. Environmental enrichment enhances neurogranin expression and hippocampal learning and memory but fails to rescue the impairments of neurogranin null mutant mice. J Neurosci. 2006;26(23):6230-7.

[151] Nithianantharajah J, Levis H, Murphy M. Environmental enrichment results in cortical and subcortical changes in levels of synaptophysin and PSD-95 proteins. Neurobiol Learn Mem. 2004;81(3):200-10.

[152] Irier H, Street RC, Dave R, Lin L, Cai C, Davis $\mathrm{TH}$, et al. Environmental enrichment modulates 5hydroxymethylcytosine dynamics in hippocampus. Genomics. 2014;104(5):376-82.

[153] Karelina K, Hansen KF, Choi YS, DeVries AC, Arthur JS, Obrietan K. MSK1 regulates environmental enrichment-induced hippocampal plasticity and cognitive enhancement. Learn Mem. 2012;19(11):550-60.

[154] Lopez-Atalaya JP, Ciccarelli A, Viosca J, Valor LM, Jimenez-Minchan M, Canals S, et al. CBP is required for environmental enrichment-induced neurogenesis and cognitive enhancement. EMBO J. 2011;30(20):4287-98.

[155] Pinaud R, Penner MR, Robertson HA, Currie RW. Upregulation of the immediate early gene arc in the brains of rats exposed to environmental enrichment: Implications for molecular plasticity. Brain Res Mol Brain Res. 2001;91(12):50-6.

[156] Zhong L, Yan CH, Lu CQ, Xu J, Huang H, Shen XM. Calmodulin activation is required for the enhancement of hippocampal neurogenesis following environmental enrichment. Neurol Res. 2009;31(7):707-13.

[157] Maass A, Duzel S, Brigadski T, Goerke M, Becke A, Sobieray U, et al. Relationships of peripheral IGF-1, VEGF and BDNF levels to exercise-related changes in 
memory, hippocampal perfusion and volumes in older adults. Neuroimage. 2016;131:142-54.

[158] Dishman RK, Berthoud HR, Booth FW, Cotman CW, Edgerton VR, Fleshner MR, et al. Neurobiology of exercise. Obesity (Silver Spring). 2006;14(3):345-56.

[159] Leger M, Bouet V, Freret T, Darmaillacq AS, Dacher M, Dauphin F, et al. Environmental enrichment improves recent but not remote memory in association with a modified brain metabolic activation profile in adult mice. Behav Brain Res. 2012;228(1):22-9.

[160] Leger M, Quiedeville A, Paizanis E, Natkunarajah S, Freret T, Boulouard M, et al. Environmental enrichment enhances episodic-like memory in association with a modified neuronal activation profile in adult mice. PLoS One. 2012;7(10):e48043.

[161] Suwabe K, Hyodo K, Byun K, Ochi G, Yassa MA, Soya $\mathrm{H}$. Acute moderate exercise improves mnemonic discrimination in young adults. Hippocampus. 2017;27(3): 229-34.

[162] Kokjohn TA, Roher AE. Amyloid precursor protein transgenic mouse models and Alzheimer's disease: Understanding the paradigms, limitations, and contributions. Alzheimer's \& Dementia: The Journal of the Alzheimer's Association. 2009;5(4):340-7.

[163] Sturchler-Pierrat C, Abramowski D, Duke M, Wiederhold $\mathrm{KH}$, Mistl C, Rothacher S, et al. Two amyloid precursor protein transgenic mouse models with Alzheimer disease-like pathology. Proc Natl Acad Sci U S A. 1997;94(24):13287-92.

[164] Gotz J, Deters N, Doldissen A, Bokhari L, Ke Y, Wiesner A, et al. A decade of tau transgenic animal models and beyond. Brain Pathol. 2007;17(1):91-103.

[165] Elder GA, Gama Sosa MA, De Gasperi R, Dickstein DL, Hof PR. Presenilin transgenic mice as models of Alzheimer's disease. Brain Struct Funct. 2010;214(23):127-43.

[166] Llorens-Martin M, Jurado J, Hernandez F, Avila J. GSK3beta, a pivotal kinase in Alzheimer disease. Front Mol Neurosci. 2014;7:46.

[167] Lucas JJ, Hernandez F, Gomez-Ramos P, Moran MA, Hen R, Avila J. Decreased nuclear beta-catenin, tau hyperphosphorylation and neurodegeneration in GSK-3beta conditional transgenic mice. EMBO J. 2001;20(1-2): 27-39.

[168] Facchinetti R, Bronzuoli MR, Scuderi C. An animal model of alzheimer disease based on the intrahippocampal injection of amyloid beta-peptide (1-42). Methods Mol Biol. 2018;1727:343-52.

[169] Bolos M, Pallas-Bazarra N, Terreros-Roncal J, Perea JR, Jurado-Arjona J, Avila J, et al. Soluble Tau has devastating effects on the structural plasticity of hippocampal granule neurons. Translational psychiatry. 2017;7(12): 1267.

[170] Clavaguera F, Akatsu H, Fraser G, Crowther RA, Frank S, Hench J, et al. Brain homogenates from human tauopathies induce tau inclusions in mouse brain. Proc Natl Acad Sci U S A. 2013;110(23):9535-40.

[171] Grinan-Ferre C, Perez-Caceres D, Gutierrez-Zetina SM, Camins A, Palomera-Avalos V, Ortuno-Sahagun D, et al. Environmental enrichment improves behavior, cognition, and brain functional markers in young senescenceaccelerated prone mice (SAMP8). Mol Neurobiol. 2016;53(4):2435-50.

[172] Unger MS, Marschallinger J, Kaindl J, Hofling C, Rossner S, Heneka MT, et al. Early changes in hippocampal neurogenesis in transgenic mouse models for Alzheimer's disease. Mol Neurobiol. 2016;53(8):5796-806.

[173] Hollands C, Bartolotti N, Lazarov O. Alzheimer's disease and hippocampal adult neurogenesis; exploring shared mechanisms. Front Neurosci. 2016;10:178.

[174] Gomez-Nicola D, Suzzi S, Vargas-Caballero M, Fransen NL, Al-Malki H, Cebrian-Silla A, et al. Temporal dynamics of hippocampal neurogenesis in chronic neurodegeneration. Brain: A Journal of Neurology. 2014;137(Pt 8):2312-28.

[175] Llorens-Martin M, Rabano A, Avila J. The ever-changing morphology of hippocampal granule neurons in physiology and pathology. Front Neurosci. 2015;9:526.

[176] Llorens-Martin M, Fuster-Matanzo A, Teixeira CM, Jurado-Arjona J, Ulloa F, Defelipe J, et al. Alzheimer disease-like cellular phenotype of newborn granule neurons can be reversed in GSK-3beta-overexpressing mice. Mol Psychiatry. 2013;18(4):395.

[177] Jessberger S, Zhao C, Toni N, Clemenson Jr GD, Li Y, Gage FH. Seizure-associated, aberrant neurogenesis in adult rats characterized with retrovirus-mediated cell labeling. J Neurosci. 2007;27(35):9400-7.

[178] Llorens-Martin M, Jurado-Arjona J, Bolos M, PallasBazarra N, Avila J. Forced swimming sabotages the morphological and synaptic maturation of newborn granule neurons and triggers a unique pro-inflammatory milieu in the hippocampus. Brain Behav Immun. 2016;53: 242-54.

[179] Bolos M, Perea JR, Terreros-Roncal J, Pallas-Bazarra N, Jurado-Arjona J, Avila J, et al. Absence of microglial CX3CR1 impairs the synaptic integration of adult-born hippocampal granule neurons. Brain Behav Immun. 2017.

[180] Llorens-Martin M, Jurado-Arjona J, Fuster-Matanzo A, Hernandez F, Rabano A, Avila J. Peripherally triggered and GSK-3beta-driven brain inflammation differentially skew adult hippocampal neurogenesis, behavioral pattern separation and microglial activation in response to ibuprofen. Transl Psychiatry. 2014;4:e463.

[181] Winner B, Melrose HL, Zhao C, Hinkle KM, Yue M, Kent C, et al. Adult neurogenesis and neurite outgrowth are impaired in LRRK2 G2019S mice. Neurobiol Dis. 2011;41(3):706-16.

[182] Tripathi PP, Santorufo G, Brilli E, Borrelli E, Bozzi Y. Kainic acid-induced seizures activate GSK-3beta in the hippocampus of D2R-/- mice. Neuroreport. 2010;21(12):846-50.

[183] Roe AD, Staup MA, Serrats J, Sawchenko PE, Rissman RA. Lipopolysaccharide-induced tau phosphorylation and kinase activity-modulation, but not mediation, by corticotropin-releasing factor receptors. Eur J Neurosci. 2011;34(3):448-56.

[184] Jin Y, Kanno T, Nishizaki T. Acute restraint stress impairs induction of long-term potentiation by activating GSK3beta. Neurochem Res. 2015;40(1):36-40.

[185] Llorens-Martin M, Teixeira CM, Jurado-Arjona J, Rakwal $\mathrm{R}$, Shibato J, Soya H, et al. Retroviral induction of GSK3beta expression blocks the stimulatory action of physical exercise on the maturation of newborn neurons. Cell Mol Life Sci. 2016;73(18):3569-82.

[186] Teixeira CM, Avila J, Llorens-Martin M. Versatile use of rtTA-expressing retroviruses in the study of neurodegeneration. Oncotarget. 2017;8(7):10771-2.

[187] Pallas-Bazarra N, Kastanauskaite A, Avila J, DeFelipe J, Llorens-Martin M. GSK-3beta overexpression alters 
the dendritic spines of developmentally generated granule neurons in the mouse hippocampal dentate gyrus. Frontiers in Neuroanatomy. 2017;11:18.

[188] Peineau S, Taghibiglou C, Bradley C, Wong TP, Liu L, Lu $\mathrm{J}$, et al. LTP inhibits LTD in the hippocampus via regulation of GSK3beta. Neuron. 2007;53(5):703-17.

[189] Hooper C, Markevich V, Plattner F, Killick R, Schofield E, Engel T, et al. Glycogen synthase kinase-3 inhibition is integral to long-term potentiation. Eur J Neurosci. 2007;25(1):81-6.

[190] Arendt T. Synaptic plasticity and cell cycle activation in neurons are alternative effector pathways: The 'Dr. Jekyll and Mr. Hyde concept' of Alzheimer's disease or the yin and yang of neuroplasticity. Prog Neurobiol. 2003;71(23):83-248.

[191] Bradley CA, Peineau S, Taghibiglou C, Nicolas CS, Whitcomb DJ, Bortolotto ZA, et al. A pivotal role of GSK-3 in synaptic plasticity. Front Mol Neurosci. 2012;5:13.

[192] Ittner LM, Ke YD, Delerue F, Bi M, Gladbach A, van Eersel J, et al. Dendritic function of tau mediates amyloidbeta toxicity in Alzheimer's disease mouse models. Cell. 2010;142(3):387-97.

[193] Bruel-Jungerman E, Laroche S, Rampon C. New neurons in the dentate gyrus are involved in the expression of enhanced long-term memory following environmental enrichment. Eur J Neurosci. 2005;21(2):513-21.

[194] Cotman CW, Berchtold NC, Christie LA. Exercise builds brain health: Key roles of growth factor cascades and inflammation. Trends Neurosci. 2007;30(9):464-72.

[195] Berchtold NC, Castello N, Cotman CW. Exercise and timedependent benefits to learning and memory. Neuroscience. 2010;167(3):588-97.

[196] Ashokan A, Hegde A, Mitra R. Short-term environmental enrichment is sufficient to counter stress-induced anxiety and associated structural and molecular plasticity in basolateral amygdala. Psychoneuroendocrinology. 2016;69:189-96.

[197] Fernandez-Teruel A, Escorihuela RM, Castellano B, Gonzalez B, Tobena A. Neonatal handling and environmental enrichment effects on emotionality, novelty/reward seeking, and age-related cognitive and hippocampal impairments: Focus on the Roman rat lines. Behav Genet. 1997;27(6):513-26.

[198] Hendriksen H, Meulendijks D, Douma TN, Bink DI, Breuer ME, Westphal KG, et al. Environmental enrichment has antidepressant-like action without improving learning and memory deficits in olfactory bulbectomized rats. Neuropharmacology. 2012;62(1):270-7.

[199] Segal SK, Cotman CW, Cahill LF. Exercise-induced noradrenergic activation enhances memory consolidation in both normal aging and patients with amnestic mild cognitive impairment. J Alzheimers Dis. 2012;32(4):1011-8.

[200] Winchester J, Dick MB, Gillen D, Reed B, Miller B, Tinklenberg J, et al. Walking stabilizes cognitive functioning in Alzheimer's disease (AD) across one year. Archives of Gerontology and Geriatrics. 2013;56(1):96-103.

[201] Xu H, Gelyana E, Rajsombath M, Yang T, Li S, Selkoe D. Environmental enrichment potently prevents microgliamediated neuroinflammation by human amyloid betaprotein oligomers. J Neurosci. 2016;36(35):9041-56.

[202] Fernandez CI, Collazo J, Bauza Y, Castellanos MR, Lopez O. Environmental enrichment-behavior-oxidative stress interactions in the aged rat: Issues for a therapeutic approach in human aging. Ann N Y Acad Sci. 2004;1019:53-7.
[203] Grinan-Ferre C, Puigoriol-Illamola D, Palomera-Avalos V, Perez-Caceres D, Companys-Alemany J, Camins A, et al. Environmental enrichment modified epigenetic mechanisms in SAMP8 mouse hippocampus by reducing oxidative stress and inflammaging and achieving neuroprotection. Front Aging Neurosci. 2016;8:241.

[204] Bennett JC, McRae PA, Levy LJ, Frick KM. Longterm continuous, but not daily, environmental enrichment reduces spatial memory decline in aged male mice. Neurobiol Learn Mem. 2006;85(2):139-52.

[205] Freret T, Billard JM, Schumann-Bard P, Dutar P, Dauphin F, Boulouard M, et al. Rescue of cognitive aging by long-lasting environmental enrichment exposure initiated before median lifespan. Neurobiol Aging. 2012;33(5):1005 e1-10.

[206] Kempermann G, Gast D, Gage FH. Neuroplasticity in old age: Sustained fivefold induction of hippocampal neurogenesis by long-term environmental enrichment. Ann Neurol. 2002;52(2):135-43.

[207] Kumar A, Rani A, Tchigranova O, Lee WH, Foster TC. Influence of late-life exposure to environmental enrichment or exercise on hippocampal function and CA1 senescent physiology. Neurobiol Aging. 2012;33(4):828 e1-17.

[208] Leal-Galicia P, Castaneda-Bueno M, Quiroz-Baez R, Arias C. Long-term exposure to environmental enrichment since youth prevents recognition memory decline and increases synaptic plasticity markers in aging. Neurobiol Learn Mem. 2008;90(3):511-8.

[209] Morse SJ, Butler AA, Davis RL, Soller IJ, Lubin FD. Environmental enrichment reverses histone methylation changes in the aged hippocampus and restores agerelated memory deficits. Biology (Basel). 2015;4(2):298313.

[210] Neidl R, Schneider A, Bousiges O, Majchrzak M, Barbelivien A, de Vasconcelos AP, et al. Late-life environmental enrichment induces acetylation events and nuclear factor kappab-dependent regulations in the hippocampus of aged rats showing improved plasticity and learning. J Neurosci. 2016;36(15):4351-61.

[211] Kline AE, Wagner AK, Westergom BP, Malena RR, Zafonte RD, Olsen AS, et al. Acute treatment with the 5-HT(1A) receptor agonist 8-OH-DPAT and chronic environmental enrichment confer neurobehavioral benefit after experimental brain trauma. Behav Brain Res. 2007;177(2):186-94.

[212] Monaco CM, Mattiola VV, Folweiler KA, Tay JK, Yelleswarapu NK, Curatolo LM, et al. Environmental enrichment promotes robust functional and histological benefits in female rats after controlled cortical impact injury. Exp Neurol. 2013;247:410-8.

[213] Cechetti F, Worm PV, Lovatel G, Moyses F, Siqueira IR, Netto CA. Environmental enrichment prevents behavioral deficits and oxidative stress caused by chronic cerebral hypoperfusion in the rat. Life Sci. 2012;91(1-2):29-36.

[214] Chen GF, Zhang YF, Long Q, Wen W, Xu MQ, Yang YL. Effects of environmental enrichment on the repair and proliferation of neurons in neonatal rats with hypoxicischemic brain damage. Zhongguo Dang Dai Er Ke Za Zhi. 2012;14(2):139-43.

[215] Diaz R, Miguel PM, Deniz BF, Confortim HD, Barbosa S, Mendonca MCP, et al. Environmental enrichment attenuates the blood brain barrier dysfunction induced by the neonatal hypoxia-ischemia. Int $\mathrm{J}$ Dev Neurosci. 2016;53:35-45. 
[216] Duran-Carabali LE, Arcego DM, Odorcyk FK, Reichert L, Cordeiro JL, Sanches EF, et al. Prenatal and early postnatal environmental enrichment reduce acute cell death and prevent neurodevelopment and memory impairments in rats submitted to neonatal hypoxia ischemia. Mol Neurobiol. 2017.

[217] Gaulke LJ, Horner PJ, Fink AJ, McNamara CL, Hicks RR. Environmental enrichment increases progenitor cell survival in the dentate gyrus following lateral fluid percussion injury. Brain Res Mol Brain Res. 2005;141(2): 138-50.

[218] Hicks RR, Zhang L, Atkinson A, Stevenon M, Veneracion M, Seroogy KB. Environmental enrichment attenuates cognitive deficits, but does not alter neurotrophin gene expression in the hippocampus following lateral fluid percussion brain injury. Neuroscience. 2002;112(3):631-7.

[219] Komitova M, Perfilieva E, Mattsson B, Eriksson PS, Johansson BB. Effects of cortical ischemia and postischemic environmental enrichment on hippocampal cell genesis and differentiation in the adult rat. J Cereb Blood Flow Metab. 2002;22(7):852-60.

[220] Gajhede Gram M, Gade L, Wogensen E, Mogensen J, Mala $\mathrm{H}$. Equal effects of typical environmental and specific social enrichment on posttraumatic cognitive functioning after fimbria-fornix transection in rats. Brain Res. 2015;1629:182-95.

[221] Kapgal V, Prem N, Hegde P, Laxmi TR, Kutty BM. Long term exposure to combination paradigm of environmental enrichment, physical exercise and diet reverses the spatial memory deficits and restores hippocampal neurogenesis in ventral subicular lesioned rats. Neurobiol Learn Mem. 2016;130:61-70.

[222] Hutchinson KM, McLaughlin KJ, Wright RL, Bryce Ortiz J, Anouti DP, Mika A, et al. Environmental enrichment protects against the effects of chronic stress on cognitive and morphological measures of hippocampal integrity. Neurobiol Learn Mem. 2012;97(2):250-60.

[223] Llorens-Martin M, Tejeda GS, Trejo JL. Antidepressant and proneurogenic influence of environmental enrichment in mice: Protective effects vs recovery. Neuropsychopharmacology. 2011;36(12):2460-8.

[224] Llorens-Martin MV, Rueda N, Martinez-Cue C, TorresAleman I, Florez J, Trejo JL. Both increases in immature dentate neuron number and decreases of immobility time in the forced swim test occurred in parallel after environmental enrichment of mice. Neuroscience. 2007;147(3):631-8.

[225] Jeong YH, Kim JM, Yoo J, Lee SH, Kim HS, Suh YH. Environmental enrichment compensates for the effects of stress on disease progression in $\mathrm{Tg} 2576$ mice, an Alzheimer's disease model. J Neurochem. 2011;119(6):1282-93.

[226] Bredy TW, Humpartzoomian RA, Cain DP, Meaney MJ. Partial reversal of the effect of maternal care on cognitive function through environmental enrichment. Neuroscience. 2003;118(2):571-6.

[227] Bredy TW, Zhang TY, Grant RJ, Diorio J, Meaney MJ. Peripubertal environmental enrichment reverses the effects of maternal care on hippocampal development and glutamate receptor subunit expression. Eur J Neurosci. 2004;20(5):1355-62.

[228] Fan Y, Liu Z, Weinstein PR, Fike JR, Liu J. Environmental enrichment enhances neurogenesis and improves functional outcome after cranial irradiation. Eur J Neurosci. 2007;25(1):38-46.
[229] Ruitenberg MJ, Wells J, Bartlett PF, Harvey AR, Vukovic J. Enrichment increases hippocampal neurogenesis independent of blood monocyte-derived microglia presence following high-dose total body irradiation. Brain Res Bull. 2017;132:150-9.

[230] Barichello T, Fagundes GD, Generoso JS, Dagostin CS, Simoes LR, Vilela MC, et al. Environmental enrichment restores cognitive deficits induced by experimental childhood meningitis. Rev Bras Psiquiatr. 2014;36(4):322-9.

[231] Kentner AC, Khoury A, Lima Queiroz E, MacRae M. Environmental enrichment rescues the effects of early life inflammation on markers of synaptic transmission and plasticity. Brain Behav Immun. 2016;57:151-60.

[232] Musaelyan K, Egeland M, Fernandes C, Pariante CM, Zunszain PA, Thuret S. Modulation of adult hippocampal neurogenesis by early-life environmental challenges triggering immune activation. Neural Plast. 2014;2014:194396.

[233] Beauquis J, Roig P, De Nicola AF, Saravia F. Short-term environmental enrichment enhances adult neurogenesis, vascular network and dendritic complexity in the hippocampus of type 1 diabetic mice. PLoS One. 2010;5(11):e13993.

[234] Gergerlioglu HS, Oz M, Demir EA, Nurullahoglu-Atalik KE, Yerlikaya FH. Environmental enrichment reverses cognitive impairments provoked by Western diet in rats: Role of corticosteroid receptors. Life Sci. 2016;148: 279-85.

[235] Pamidi N, Nayak S. Effect of environmental enrichment exposure on neuronal morphology of streptozotocininduced diabetic and stressed rat hippocampus. Biomed J. 2014;37(4):225-31.

[236] Fares RP, Belmeguenai A, Sanchez PE, Kouchi HY, Bodennec J, Morales A, et al. Standardized environmental enrichment supports enhanced brain plasticity in healthy rats and prevents cognitive impairment in epileptic rats. PLoS One. 2013;8(1):e53888.

[237] Gobbo OL, O'Mara SM. Exercise, but not environmental enrichment, improves learning after kainic acid-induced hippocampal neurodegeneration in association with an increase in brain-derived neurotrophic factor. Behav Brain Res. 2005;159(1):21-6.

[238] Korbey SM, Heinrichs SC, Leussis MP. Seizure susceptibility and locus ceruleus activation are reduced following environmental enrichment in an animal model of epilepsy. Epilepsy Behav. 2008;12(1):30-8.

[239] Guilarte TR, Toscano CD, McGlothan JL, Weaver SA. Environmental enrichment reverses cognitive and molecular deficits induced by developmental lead exposure. Ann Neurol. 2003;53(1):50-6.

[240] Ji MH, Wang XM, Sun XR, Zhang H, Ju LS, Qiu LL, et al. Environmental enrichment ameliorates neonatal sevoflurane exposure-induced cognitive and synaptic plasticity impairments. J Mol Neurosci. 2015;57(3):358-65.

[241] Ji MH, Wang ZY, Sun XR, Tang H, Zhang H, Jia M, et al. Repeated neonatal sevoflurane exposure-induced developmental delays of parvalbumin interneurons and cognitive impairments are reversed by environmental enrichment. Mol Neurobiol. 2017;54(5):3759-70.

[242] Parks EA, McMechan AP, Hannigan JH, Berman RF. Environmental enrichment alters neurotrophin levels after fetal alcohol exposure in rats. Alcohol Clin Exp Res. 2008;32(10):1741-51.

[243] Tyler CR, Allan AM. Adult hippocampal neurogenesis and mRNA expression are altered by perinatal arsenic expo- 
sure in mice and restored by brief exposure to enrichment. PLoS One. 2013;8(9):e73720.

[244] Winocur G, Wojtowicz JM, Merkley CM, Tannock IF. Environmental enrichment protects against cognitive impairment following chemotherapy in an animal model. Behav Neurosci. 2016;130(4):428-36.

[245] Burrows EL, McOmish CE, Buret LS, Van den Buuse M, Hannan AJ. Environmental enrichment ameliorates behavioral impairments modeling schizophrenia in mice lacking metabotropic glutamate receptor 5. Neuropsychopharmacology. 2015;40(8):1947-56.

[246] McOmish CE, Burrows E, Howard M, Scarr E, Kim D, Shin HS, et al. Phospholipase C-betal knockout mice exhibit endophenotypes modeling schizophrenia which are rescued by environmental enrichment and clozapine administration. Mol Psychiatry. 2008;13(7):661-72.

[247] Yamaguchi H, Hara Y, Ago Y, Takano E, Hasebe S, Nakazawa T, et al. Environmental enrichment attenuates behavioral abnormalities in valproic acid-exposed autism model mice. Behav Brain Res. 2017;333:67-73.

[248] Hendriksen H, Prins J, Olivier B, Oosting RS. Environmental enrichment induces behavioral recovery and enhanced hippocampal cell proliferation in an antidepressant-resistant animal model for PTSD. PLoS One. 2010;5(8):e11943.

[249] Illa M, Brito V, Pla L, Eixarch E, Arbat-Plana A, Batalle D, et al. Early environmental enrichment enhances abnormal brain connectivity in a rabbit model of intrauterine growth restriction. Fetal Diagn Ther. 2017.

[250] Soares RO, Horiquini-Barbosa E, Almeida SS, Lachat JJ. Environmental enrichment protects spatial learning and hippocampal neurons from the long-lasting effects of protein malnutrition early in life. Behav Brain Res. 2017;335:55-62.

[251] Jamal I, Kumar V, Vatsa N, Singh BK, Shekhar S, Sharma A, et al. Environmental enrichment improves behavioral abnormalities in a mouse model of angelman syndrome. Mol Neurobiol. 2017;54(7):5319-26.

[252] Kondo M, Gray LJ, Pelka GJ, Christodoulou J, Tam PP, Hannan AJ. Environmental enrichment ameliorates a motor coordination deficit in a mouse model of Rett syndrome-Mecp2 gene dosage effects and BDNF expression. Eur J Neurosci. 2008;27(12):3342-50.

[253] Lauterborn JC, Jafari M, Babayan AH, Gall CM. Environmental enrichment reveals effects of genotype on hippocampal spine morphologies in the mouse model of Fragile X Syndrome. Cereb Cortex. 2015;25(2): 516-27.

[254] Catuara-Solarz S, Espinosa-Carrasco J, Erb I, Langohr K, Gonzalez JR, Notredame C, et al. Combined treatment with environmental enrichment and (-)-epigallocatechin3-gallate ameliorates learning deficits and hippocampal alterations in a mouse model of down syndrome. eNeuro. 2016;3(5).

[255] Chakrabarti L, Scafidi J, Gallo V, Haydar TF. Environmental enrichment rescues postnatal neurogenesis defect in the male and female Ts65Dn mouse model of Down syndrome. Dev Neurosci. 2011;33(5):428-41.

[256] Llorens-Martin MV, Rueda N, Tejeda GS, Florez J, Trejo JL, Martinez-Cue C. Effects of voluntary physical exercise on adult hippocampal neurogenesis and behavior of Ts65Dn mice, a model of Down syndrome. Neuroscience. 2010;171(4):1228-40.

[257] Pons-Espinal M, Martinez de Lagran M, Dierssen M. Environmental enrichment rescues DYRK1A activity and hippocampal adult neurogenesis in TgDyrk1A. Neurobiol Dis. 2013;60:18-31.

[258] Jin X, Li T, Zhang L, Ma J, Yu L, Li C, et al. Environmental enrichment improves spatial learning and memory in vascular dementia rats with activation of wnt/beta-catenin signal pathway. Med Sci Monit. 2017;23:207-15.

[259] Lazic SE, Grote HE, Blakemore C, Hannan AJ, van Dellen A, Phillips W, et al. Neurogenesis in the R6/1 transgenic mouse model of Huntington's disease: Effects of environmental enrichment. Eur J Neurosci. 2006;23(7): 1829-38.

[260] Zajac MS, Pang TY, Wong N, Weinrich B, Leang LS, Craig $\mathrm{JM}$, et al. Wheel running and environmental enrichment differentially modify exon-specific BDNF expression in the hippocampus of wild-type and pre-motor symptomatic male and female Huntington's disease mice. Hippocampus. 2010;20(5):621-36.

[261] Ickes BR, Pham TM, Sanders LA, Albeck DS, Mohammed $\mathrm{AH}$, Granholm AC. Long-term environmental enrichment leads to regional increases in neurotrophin levels in rat brain. Exp Neurol. 2000;164(1):45-52.

[262] Llorens-Martin M, Torres-Aleman I, Trejo JL. Growth factors as mediators of exercise actions on the brain. Neuromolecular Med. 2008;10(2):99-107.

[263] Llorens-Martin M, Torres-Aleman I, Trejo JL. Mechanisms mediating brain plasticity: IGF1 and adult hippocampal neurogenesis. Neuroscientist. 2009;15(2): 134-48.

[264] Pham TM, Ickes B, Albeck D, Soderstrom S, Granholm AC, Mohammed AH. Changes in brain nerve growth factor levels and nerve growth factor receptors in rats exposed to environmental enrichment for one year. Neuroscience. 1999;94(1):279-86.

[265] Du LL, Wang L, Yang XF, Wang P, Li XH, Chai $\mathrm{DM}$, et al. Transient receptor potential-canonical 1 is essential for environmental enrichment-induced cognitive enhancement and neurogenesis. Mol Neurobiol. 2017;54(3):1992-2002.

[266] Bekinschtein P, Oomen CA, Saksida LM, Bussey TJ. Effects of environmental enrichment and voluntary exercise on neurogenesis, learning and memory, and pattern separation: BDNF as a critical variable? Semin Cell Dev Biol. 2011;22(5):536-42.

[267] Shilpa BM, Bhagya V, Harish G, Srinivas Bharath MM, Shankaranarayana Rao BS. Environmental enrichment ameliorates chronic immobilisation stress-induced spatial learning deficits and restores the expression of BDNF, VEGF, GFAP and glucocorticoid receptors. Prog Neuropsychopharmacol Biol Psychiatry. 2017;76: 88-100.

[268] Llorens-Martin M, Torres-Aleman I, Trejo JL. Exercise modulates insulin-like growth factor 1-dependent and independent effects on adult hippocampal neurogenesis and behaviour. Mol Cell Neurosci. 2010;44(2):109-17.

[269] Trejo JL, Carro E, Torres-Aleman I. Circulating insulinlike growth factor I mediates exercise-induced increases in the number of new neurons in the adult hippocampus. J Neurosci. 2001;21(5):1628-34.

[270] Trejo JL, Piriz J, Llorens-Martin MV, Fernandez AM, Bolos M, LeRoith D, et al. Central actions of liver-derived insulin-like growth factor I underlying its pro-cognitive effects. Mol Psychiatry. 2007;12(12):1118-28.

[271] Rossi C, Angelucci A, Costantin L, Braschi C, Mazzantini M, Babbini F, et al. Brain-derived neurotrophic factor (BDNF) is required for the enhancement of hippocampal 
neurogenesis following environmental enrichment. Eur J Neurosci. 2006;24(7):1850-6.

[272] Ortuzar N, Rico-Barrio I, Bengoetxea H, Argandona EG, Lafuente JV. VEGF reverts the cognitive impairment induced by a focal traumatic brain injury during the development of rats raised under environmental enrichment. Behav Brain Res. 2013;246:36-46.

[273] Hu YS, Long N, Pigino G, Brady ST, Lazarov O. Molecular mechanisms of environmental enrichment: Impairments in Akt/GSK3beta, neurotrophin-3 and CREB signaling. PLoS One. 2013;8(5):e64460.

[274] Jessberger S, Aigner S, Clemenson Jr GD, Toni N, Lie DC, Karalay O, et al. Cdk5 regulates accurate maturation of newborn granule cells in the adult hippocampus. PLoS Biol. 2008;6(11):e272.

[275] Gradari S, Palle A, McGreevy KR, Fontan-Lozano A, Trejo JL. Can exercise make you smarter, happier, and have more neurons? A hormetic perspective. Front Neurosci. 2016;10:93.

[276] Fuster-Matanzo A, Llorens-Martin M, Jurado-Arjona J, Avila J, Hernandez F. Tau protein and adult hippocampal neurogenesis. Front Neurosci. 2012;6:104.

[277] Fuster-Matanzo A, Llorens-Martin M, Sirerol-Piquer MS, Garcia-Verdugo JM, Avila J, Hernandez F. Dual effects of increased glycogen synthase kinase-3beta activity on adult neurogenesis. Hum Mol Genet. 2013;22(7):1300-15.

[278] Lie DC, Colamarino SA, Song HJ, Desire L, Mira H, Consiglio A, et al. Wnt signalling regulates adult hippocampal neurogenesis. Nature. 2005;437(7063):1370-5.

[279] Vivar C, Potter MC, van Praag H. All about running: Synaptic plasticity, growth factors and adult hippocampal neurogenesis. Curr Top Behav Neurosci. 2013;15: 189-210

[280] Allen SJ, Watson JJ, Dawbarn D. The neurotrophins and their role in Alzheimer's disease. Current Neuropharmacology. 2011;9(4):559-73.

[281] Cotel MC, Jawhar S, Christensen DZ, Bayer TA, Wirths O. Environmental enrichment fails to rescue working memory deficits, neuron loss, and neurogenesis in APP/PS1KI mice. Neurobiol Aging. 2012;33(1):96-107.

[282] Catlow BJ, Rowe AR, Clearwater CR, Mamcarz M, Arendash GW, Sanchez-Ramos J. Effects of environmental enrichment and physical activity on neurogenesis in transgenic PS1/APP mice. Brain Res. 2009;1256:173-9.

[283] Kempermann G, Gage FH. Genetic influence on phenotypic differentiation in adult hippocampal neurogenesis. Brain Res Dev Brain Res. 2002;134(1-2):1-12.

[284] Kempermann G, Gage FH. Genetic determinants of adult hippocampal neurogenesis correlate with acquisition, but not probe trial performance, in the water maze task. Eur J Neurosci. 2002;16(1):129-36.

[285] Jankowsky JL, Melnikova T, Fadale DJ, Xu GM, Slunt $\mathrm{HH}$, Gonzales V, et al. Environmental enrichment mitigates cognitive deficits in a mouse model of Alzheimer's disease. J Neurosci. 2005;25(21):5217-24.

[286] Stuart KE, King AE, Fernandez-Martos CM, Dittmann J, Summers MJ, Vickers JC. Mid-life environmental enrichment increases synaptic density in CA1 in a mouse model of Abeta-associated pathology and positively influences synaptic and cognitive health in healthy ageing. J Comp Neurol. 2017;525(8):1797-810.
[287] Valero J, Espana J, Parra-Damas A, Martin E, Rodriguez-Alvarez J, Saura CA. Short-term environmental enrichment rescues adult neurogenesis and memory deficits in $\mathrm{APP}(\mathrm{Sw}, \mathrm{Ind})$ transgenic mice. PLoS One. 2011;6(2):e16832.

[288] Need AC, Giese KP. Handling and environmental enrichment do not rescue learning and memory impairments in alphaCamKII(T286A) mutant mice. Genes Brain Behav. 2003;2(3):132-9.

[289] Veeraraghavalu K, Choi SH, Sisodia SS. Expression of familial Alzheimer's disease-linked human presenilin 1 variants impair enrichment-induced adult hippocampal neurogenesis. Neurodegener Dis. 2010;7(1-3):46-9.

[290] Herring A, Ambree O, Tomm M, Habermann H, Sachser $\mathrm{N}$, Paulus W, et al. Environmental enrichment enhances cellular plasticity in transgenic mice with Alzheimer-like pathology. Exp Neurol. 2009;216(1):184-92.

[291] Kempermann G, Brandon EP, Gage FH. Environmental stimulation of $129 / \mathrm{SvJ}$ mice causes increased cell proliferation and neurogenesis in the adult dentate gyrus. Curr Biol. 1998;8(16):939-42.

[292] Levi O, Michaelson DM. Environmental enrichment stimulates neurogenesis in apolipoprotein E3 and neuronal apoptosis in apolipoprotein E4 transgenic mice. J Neurochem. 2007;100(1):202-10.

[293] Marlatt MW, Potter MC, Bayer TA, van Praag H, Lucassen PJ. Prolonged running, not fluoxetine treatment, increases neurogenesis, but does not alter neuropathology, in the $3 \times$ Tg mouse model of Alzheimer's disease. Curr Top Behav Neurosci. 2013;15:313-40.

[294] Rodriguez JJ, Noristani HN, Olabarria M, Fletcher J, Somerville TD, Yeh CY, et al. Voluntary running and environmental enrichment restores impaired hippocampal neurogenesis in a triple transgenic mouse model of Alzheimer's disease. Curr Alzheimer Res. 2011;8(7): 707-17.

[295] Rhodes JS, van Praag H, Jeffrey S, Girard I, Mitchell GS, Garland Jr T, et al. Exercise increases hippocampal neurogenesis to high levels but does not improve spatial learning in mice bred for increased voluntary wheel running. Behav Neurosci. 2003;117(5):1006-16.

[296] Dawson HN, Ferreira A, Eyster MV, Ghoshal N, Binder LI, Vitek MP. Inhibition of neuronal maturation in primary hippocampal neurons from tau deficient mice. Journal of cell science. 2001;114(Pt 6):1179-87.

[297] Zhao C, Jou J, Wolff LJ, Sun H, Gage FH. Spine morphogenesis in newborn granule cells is differentially regulated in the outer and middle molecular layers. J Comp Neurol. 2014;522(12):2756-66.

[298] Selkoe DJ. Preventing Alzheimer's disease. Science. 2012;337(6101):1488-92.

[299] Heneka MT, Carson MJ, El Khoury J, Landreth GE, Brosseron F, Feinstein DL, et al. Neuroinflammation in Alzheimer's disease. Lancet Neurol. 2015;14(4):388-405.

[300] Kempermann G, Kuhn HG, Gage FH. Experience-induced neurogenesis in the senescent dentate gyrus. J Neurosci. 1998;18(9):3206-12.

[301] Aigner S, Denli AM, Gage FH. A novel model for an older remodeler: The BAF swap in neurogenesis. Neuron. 2007;55(2):171-3. 